\title{
PERLINDUNGAN HUKUM BAGI PARA PIHAK (KREDITUR DAN DEBITUR) MELALUI PARATE EXECUTIE OBYEK HAK TANGGUNGAN
}

\author{
LEGAL PROTECTION FOR PARTIES (CREDITOR AND \\ DEBTOR) THOROUGH PARATE EXECUTE OBJECT OF \\ MORTGAGE
}

\author{
Hirsanuddin \\ Universitas Mataram \\ Email: hirsanuddin2019@gmail.com \\ Sudiarto \\ Universitas Mataram \\ Email : sudiartofh@unram.ac.id
}

\begin{abstract}
This research aims to find out and analysis uncertainty of legal protection for creditor through Parate Execute the object of mortgage. The method of this research is normative legal research using statute and conceptual approach. Analyzing legal material is conducted by descriptif-qualitative technique. The result of this research experienced that protection for creditor in execution of mortgage is not strong due to it is not in accordance with Article 6 Mortgage Law which stated that creditor can do the auction himself if in mortgage deed is stated that first mortgage holder has rights to sell the object of mortgage if debtor breaches of contract (Mortgage Law in Article 11 Paragraph (2) letter e). In addition, the state auction office is not willing to carry out an auction for the object of mortgage because there must be fiat from the head of the district court. Based on the general explanation of the Mortgage Law number 9 in conjunction with the explanation of Article 14 paragraph (2) and (3) UUHT it is determined that the execute implementation procedure must be based on Article $224 \mathrm{HIR}$, which must obtain fiat from the Head of the District Court. It can cause losses to creditors, due to additional costs and long execution time.
\end{abstract}

\section{Keywords: Protection; Mortgage; Parate Execute}

\begin{abstract}
Abstrak
Tujuan penelitian ini adalah untuk menganalisis tentang adanya ketidak pastian perlindungan hukum bagi kreditur melalui Parate Executie obyek hak tanggungan. Jenis penelitian yang dilakukan dalam penelitian adalah penelitian hukum normatif dengan menggunakan pendekatan perundang-undangan, konseptual. Analisis bahan hukum dilakukan dengan teknik deskriftif kualitatif. Berdasarakan hasil penelitian diperoleh bahwa bentuk perlindungan bagi kreditur dalam eksekusi hak tanggungan sangat lemah karena tidak sesesuai dengan apa yang tertuang dalam Pasal 6 UUHT yang menentukan kreditur dapat melakukan pelelangan sendiri jika dalam APHT dicantumkan janji bahwa pemegang hak tanggungan pertama mempunyai hak untuk menjual sendiri obyek hak tanggungan apabila debitur cidera janji (Pasal 11 ayat (2) huruf e UUHT). Di samping itu kantor lelang negara tidak bersedia melaksanakan
\end{abstract}


lelang obyek hak tanggungan dengan alasan harus ada fiat dari ketua pengadilan negeri, karena berdasarkan penjelasan umum UUHT angka 9 jo penjelasan Pasal 14 ayat (2) dan (3) UUHT ditentukan bahwa prosedur pelaksanaan executie harus berdasarkan Pasal 224 HIR yang harus mendapatkan fiat dari Ketua Pengadilan Negeri, hal ini bisa menimbulkan kerugian bagi kreditur, karena adanya penambahan biaya dan waktu executie yang lama.

\section{Kata kunci: Perlindungan; Hak Tanggungan; Parate Executie}

\section{PENDAHULUAN}

Bagi masyarakat, perorangan atau badan usaha yang berusaha meningkatkan kebutuhan komsumtif atau produktif sangat membutuhkan pendanaan dari bank sebagai salah satu sumber dana yang di antaranya dalam bentuk perkreditan, agar mampu mencukupi dalam mendukung peningkatan usahanya ${ }^{1}$.

Dalam proses pemberian kredit sering terjadi bahwa pihak kreditur dirugikan ketika pihak debitur melakukan wanprestasi, sehingga diperlukan suatu aturan hukum dalam pelaksanaan pembebanan hak tanggungan yang tertuang dalam suatu perjanjian kredit, yang bertujuan untuk memberikan kepastian dan perlindungan hukum bagi pihakpihak terkait, khususnya bagi pihak kreditur apabila debitur wanprestasi atau tidak memenuhi kewajibannya ${ }^{2}$.

Ada beberapa persoalan yang menyebabkan terjadinya kredit bermasalah misalnya karena debitur tidak mampu atau karena mengalami kemerosotan usaha dan gagalnya usaha yang mengakibatkan berkurangnya pendapatan usaha debitur atau memang debitur sengaja tidak mau membayar karena karakter debitur tidak baik ${ }^{3}$.

Mengingat pentingnya kedudukan dana perkreditan dalam proses pembangunan, sudah semestinya jika pemberi dan penerima kredit serta pihak lain yang terkait mendapat perlindungan melalui suatu lembaga hak jaminan yang kuat agar dapat memberikan kepastian hukum bagi semua pihak yang berkepentingan sebagai upaya mengantisipasi timbulnya resiko bagi kreditur pada masa yang akan datang ${ }^{4}$.

Untuk mengantisipasi resiko tersebut ada beberapa solusi yang dapat dilakukan adalah prosedur mengenai pelaksanaan pemenuhan prestasi apabila debitor wanprestasi. Memang saat ini ada banyak alternatif tentang eksekusi (pelaksanaan) terhadap obyek jaminan manakala debitor wanprestasi, namun tentunya eksekusi mana yang paling mudah prosedurnya untuk mempercepat pelunasan piutangnya sehingga bisa mendukung pembangunan ekonomi nasiona $1^{5}$.

Lembaga jaminan oleh lembaga perbankan dianggap paling efektif dan aman adalah tanah dengan jaminan Hak Tanggungan. Hal itu didasari adanya kemudahan dalam mengidentifikasi obyek Hak Tanggungan, jelas dan pasti eksekusinya, di samping itu hutang yang dijamin dengan Hak Tanggungan harus dibayar terlebih dahulu

\footnotetext{
${ }^{1}$ Herowati Poesoko, 2012, Dinamika Hukum Parate Executie Obyek Hak Tanggungan, Aswaja Pressindo, Yogyakarta, hlm. 1.

${ }^{2}$ Rahmi Rimanda dan Yusri, Perlindungan Hukum Bagi Kreditur Dalam Pembiayaan Dengan Jaminan Hak Tanggungan (Studi pada Kantor Pusat PT. Bank Aceh Syariah di Provinsi Aceh), Jurnal Ilmiah Mahasiswa Bidang Hukum Keperdataan, Fakultas Hukum Universitas Syiah Kuala, Volume 3 (1) Februari 2019, hlm. 158.

${ }^{3}$ Lusia Sulastri, Konstutusi Perlindungan Hukum Debitur Dalam Penyelesaian Kredit Bermasalah Dengan Pelaksanaan Lelang Jaminan Hak Tanggungan, Jurnal Pembaharuan Hukum Volume II No. 1 Januari-April 2015, hlm. 87.

${ }^{5}$ Sony Harsono, 1996, Sambutan Menteri Agraria/Kepala BPNpada Seminar Hak Tanggungan alas Tanah dan Benda-Benda yang Berkaitan dengan Tanah, Fakultas Hukum UNPAD, Bandung.
} 
dari tagihan lainnya dengan uang hasil pelelangan tanah yang menjadi obyek Hak Tanggungan ${ }^{6}$, memang hal yang tidak dapat diabaikan dalam perjanjian kredit adalah perlindungan hukum bagi kreditor manakala debitor wanprestasi, apalagi kalau debitor sampai mengalami kemacetan dalam pembayarannya. Pemanfaatan lembaga eksekusi Hak Tanggungan dengan demikian merupakan cara percepatan pelunasan piutang agar dana yang telah dikeluarkan itu dapat segera kembali kepada kreditor (Bank), dan dana tersebut dapat digunakan dalam perputaran roda perekonomian ${ }^{7}$.

Kemudahan yang disediakan oleh UUHT bagi para kreditor pemegang Hak Tanggungan manakala debitor cidera janji, berdasarkan Pasal 20 ayat (1) huruf a dan b UUHT eksekusi atas benda jaminan Hak Tanggungan dapat ditempuh melalui 3 (tiga) cara yaitu:

a. parate executie;

b. title executorial; dan

c. penjualan di bawah tangan.

Apabila ditelusuri pengaturan parate executie dalam UUHT terdapat kerancuan. Kerancuan pengaturan parate executie tersebut, terlihat bilamana dihubungkan antara Pasal 6 UUHT yang menyatakan pelaksanaannya melalui lelang umum sedangkan Penjelasan Umum angka 9 menentukan agar parate executie pelaksanaannya mendasarkan kepada Pasal 224 H.I.R.. Pengaturan eksekusi menurut Pasal 224 H.I.R. adalah eksekusi yang ditujukan kepada grosse acte hipotik dan grosse acte pengakuan hutang. Kedua grosse acte tersebut dimaksudkan, memang mempunyai hak eksekutorial, yang berarti kedua grosse acte tersebut mempunyai kekuatan sebagai suatu putusan pengadilan yang mempunyai kekuatan hukum yang tetap. Maka eksekusinya tunduk dan patuh sebagaimana pelaksanaan suatu putusan pengadilan, yang harus dilaksanakan atas perintah Ketua Pengadilan Negeri.

Adanya kerancuan atas pengaturan parate executie dan praktek hukum di pengadilan yang menimbulkan kebingungan dapat mengganggu kepastian hukum bagi jaminan Hak Tanggungan, yang dapat memberikan dampak membuat merosotnya kepercayaan para pelaku ekonomi terhadap perangkat hukum. Hal tersebut menurut M. Isnaeni ${ }^{8}$ sangat dirasakan bahwa benteng penangkal yang disediakan oleh perangkat hukum, yang dipergunakan dalam transaksi dagang, ternyata dalam beberapa hal tidak efektif lagi untuk menangkis resiko kerugian. Ganjalan semacam itu tentunya bisa mendatangkan keresahan dalam rangka memacu pertumbuhan ekonomi yang sedang digalakkan dewasa ini. Perangkat hukum yang mestinya dapat diandalkan agar bisa ikut membantu menopang era pertumbuhan ekonomi, ternyata perannya tidak bisa efektif secara optimal.

Berdasarkan latar belakang di atas, maka dapat dirumuskan beberapa permasalahan, yaitu:

1. Bagaimanakah perlindungan hukum kreditur dan debitur terhadap pelelangan melalui parate executie obyek hak tanggungan?

\footnotetext{
${ }^{6}$ Retnowulan Sutantio, 1999, Penelitian Tentang Perlindungan Hukum Eksekusi Jaminan Kredit, Badan Pembinaan Hukum Nasional-Departemen Kehakiman RI, Jakarta, hlm. 8.

${ }^{7}$ Ibid

${ }^{8}$ M. Isnaeni, 1996, Hipotek Pesawat Udara Dilndonesia, CV. Dharma Muda, Surabaya, hlm. 43.
} 
2. Hambatan-hambatan apa yang dihadapi dalam melindungi kepentingan kreditur dan debitur terhadap pelelangan obyek hak tanggungan melalui parate executie dan apa solusi untuk mengatasi hambatan-hamabatan tersebut?

Adapun jenis penelitian yang digunakan dalam penelitian ini adalah penelitian hukum normatif, dengan menggunakan pendekatan peraturan perundang-undangan dan konseptual. Sedangkan metode analisis yang digunakan adalah metode analisis deskriptif kualitatif.

\section{PEMBAHASAN}

\section{Perlindungan Hukum Kreditur Dan Debitur Terhadap Pelelangan Melalui Pa- rate Executie Obyek Hak Tanggungan.}

Setiap hubungan hukum menimbulkan hak dan kewajiban. Dalam hubungan hukum terdapat hak dan kewajiban pihak yang satu berhadapan dengan hak dan kewajiban pihak yang lain. Salah satu bentuk hubungan hukum yang dibuat oleh para pihak dituangkan dalam perjanjian. Perjanjian adalah sebuah kesepakatan yang dibuat oleh para pihak yang membuat perjanjian. Para pihak sepakat untuk mengikatkan diri satu dengan lainnya, baik untuk memberikan sesuatu, berbuat sesuatu/tidak berbuat sesuatu. ${ }^{9}$

. Tentunya dalam rangkaian janji-janji itu terangkum hak dan kewajiban masingmasing pihak dan janji-janji tersebut harus ditepati. Manakala antara mereka ada yang ingkar janji, tentu menimbulkan kerugian bagi pihak lain yang mengadakan perjanjian. Untuk menjamin dipenuhinya kewajiban yang timbul dari suatu perikatan hukum diperlukan adanya suatu jaminan yang dapat dinilai dengan uang. ${ }^{10}$

Perjanjian jaminan yang dibuat antara kreditur (Bank) dengan debitur atau pihak ketiga yang membuat suatu janji dengan mengikatkan benda tertentu atau kesanggupan pihak ketiga dengan tujuan memberikan keamanan dan kepsatian hukum pengembalian kredit atau pelaksanaan perjanjian pokok ${ }^{11}$. Penyebutan jaminan yang diikat dengan benda tertentu yang diperjanjikan antara kreditor dengan debitor dan atau pihak ketiga, dapat dipahami sebagai konsekuensi logis atas adanya jaminan kebendaan dan jaminan perorangan.

Dalam perjanjian jaminan perorangan tidak jelas benda apa atau yang mana milik pihak ketiga yang akan menjadi jaminan, sehingga disini akan berlaku ketentuan seperti dalam jaminan umum yang diberikan oleh undang-undang lewat Pasal 1131 dan Pasal 1132 B.W. maka hanya memberikan kedudukan yang sama diantara pada kreditor yaitu sebagai kreditor konkuren saja ${ }^{12}$. Pada jaminan perorangan sifat-sifatnya antara lain tidak mutlak (relatif), sebab hak jaminan perorangan hanya dapat dipertahankan terhadap orang atau pihak tertentu yang terikat dalam perjanjian yang dimaksudkan

\footnotetext{
${ }^{9}$ M. Arba dan Diman Ade Mulada, 2020, Hukum Hak Tanggungan, Hak Tanggungan Atas Tanah dan Benda-Benda di Atasnya, Sinar Grafika, Jakarta, hlm. 165.

${ }^{10}$ Herowati Poesoko, 2007: Parate Executie Obyek Hak Tanggungan (Inkositensi, Konflik Norma dan Kesesatan Penalaran dalam UUHT), Laks Bang PRESSindo, Yogyakarta, hlm. 31.

${ }^{11}$ Djuhaendah Hasan, (1996), Lembaga Jaminan Kebendaan Bagi Tanah dan Benda Lain yang Melekat Pada Tanah Dalam Konsepsi Penerapan Asas Pemisahan Horisontal, Citra Aditya Bakti, Bandung, hlm. 236.

${ }_{12}$ Ari Purwadi, Problematika Hak Tanggungan Menurut Undang-Undang Nomor 4 Tahun 1996. Jurnal Hukum Ekonomi, Edisi IX Agustus 1997, hlm. 71.
} 
dan tidak mengikat terhadap setiap orang sebagaimana dalam perjanjian jaminan kebendaan yagn mempunyai sifat absolut. Demikian pula hak jaminan perorangan tidak memberikan preferensi dan tidak ada azas prioritas yang ada hanya azas kesamaan.

Berbeda apabila perjanjian kredit tersebut disertai dengan adanya jaminan kebendaan, karena dengan adanya jaminan tersebut selain membuat posisi kreditor menjadi kreditor Preverent, juga sebagai bentuk upaya perlindungan hukum bagi kreditor ${ }^{13}$. Apabila debitor wanprestasi maka kreditor dapat melaksanakan eksekusi atas obyek jaminan milik debitor ${ }^{14}$.

Selain bertujuan memberikan perlindungan aset kepada kreditor, Jaminan Kebendaan tersebut juga harus mampu memberikan perlindungan aset terhadap harta Debitor. Agar harta debitor yang dijadikan jaminan tidak dieksekusi sembarangan, namun perlu memperhatikan harga jual barang yang ada di pasaran dan nilai dari fasilitas kredit yang diberikan.

Di dalam UUHT terdapat ketentuan yang mengatur tentang pelaksanaan eksekusi secara tersendiri. Memang pada dasarnya Pasal 6 UUHT sebagai dasar kuat dari kreditor pemegang Hak Tanggungan guna melakukan eksekusi dalam rangka pelunasan utang debitur. Ketentuan ini mengandung pengertian parate eksekusi dengan menjual atas kekuasaan sendiri (egenmachtige verkoop) dapat dilakukan apabila dituangkan dalam surat perjanjian. Sebaliknya apabila tidak ditentukan dalam surat perjanjian, maka eksekusi dilakukan melalui permohonan kepada pengadilam agar dilakukan penjualan lelang dengan alasan cedera janji. Hal tersebut tidak mengurangi asas Hak Tanggungan yang bersifat mudah dan pasti, karena semata-mata mengkuti ketentuan yang diatur dalam peraturan perundang-undangan ${ }^{15}$. Dalam Pasal 20 ayat (1) UUHT yang mengatur mengenai Eksekusi Hak Tanggungan menjelaskan bahwa menjual obyek Hak Tanggungan atas kekuasaan sendiri atau parate executie dapat dilaksanakan dengan cara menjual Obyek Hak Tanggungan melalui pelelangan umum. Hal tersebut dijelaskan pada penjelasan Pasal 20 ayat (1) UUHT, dimana pada prinsipnya setiap eksekusi haruslah melalui pelelangan umum, karena diharapkan melalui pelelangan umum tersebut didapatkan harga yang paling tinggi atau setidaknya didapatkan harga yang sesuai dengan nilai Obyek Hak Tanggungan tersebut di pasaran. Akan tetapi dalam Pasal 20 ayat (2) dan ayat (3) UUHT mencoba membuka peluang bagi kreditor pemegang Hak Tanggungan untuk menyimpangi ketentuan yang ada dalam Pasal 20 ayat (1) UUHT tersebut. Dalam Pasal 20 ayat (2) dan ayat (3) UUHT menjelaskan bahwa kreditor pemegang Hak Tanggungan dapat melakukan eksekusi tanpa melalui pelelangan umum, melainkan melalui penjualan dibawah tangan sepanjang para pihak pemberi dan pemegang Hak Tanggungan menyepakatinya, dengan harapan bawa melalui penjualan di bawah tangan tersebut akan dapat diperoleh harga tertinggi yang dapat menguntungkan semua pihak ${ }^{16}$.

\footnotetext{
${ }^{13}$ Sutan Remy Sjahdeni, 1999, Hak Tanggungan AsasAsas, Ketentuan Pokok, dan Masalah yang Dihadapi Oleh Perbankan, Alumni, Bandung, hlm. 10.

${ }^{14}$ J. Satrio, 2007, Hukum Jaminan Hak Jaminan Kebendaan, Citra Aditya Bakti, Bandung, cetakan ke 5, hlm. 255.

${ }^{15}$ Imron Rosyadi, 2007, Jaminan Kebendaan Berdasarkan Akad Syariah (Aspek Perikatan, Prosedur Pembebanan dan Eksekusi), Kencana, hlm. 111.

${ }^{16}$ Yusuf Arif Utomo, Parate Executie Pada Hak Tanggungan Sebagai Perlindungan Aset Kreditor dan Debitor, Yuridika, Volume 26, No. 2, Mei - Agustus 2011, hlm. 187.
} 
Persoalan berikutnya, Pasal 6 Undang-Undang nomor 4 tahun 1996 tentang Hak Tanggungan Atas Tanah Beserta Benda-Benda Yang Berkaitan Dengan Tanah merupakan hukum materiil sedangkan hukum yang mengatur tentang acara mengenai eksekusi Hak Tanggungan ini mengacu pada Pasal 224 HIR (Herzien Inlandsch Reglement). Pasal 224 HIRini bersifat terbatas yaitu akta yang bisa dieksekusi langsung dan mempunyai kekuatan eksekutorial hanya sebatas Grosse Akta Hipotik dan Akta Notariil yang berisi Pengakuan Hutang, permasalahannya, dalam Parate executie Pasal 6 Undang-Undang Nomor 4 Tahun 1996 tentang Hak TanggunganAtas Tanah dan Benda-Benda yang BerkaitanDengan Tanah (hukum materiil) untuk melakukan parate eksekusi tidak diperlukan lagi adanya fiat eksekusi dari pengadilan sedangkan dalam Pasal 224 HIR (hukum formil) ditentukan bahwa untuk eksekusi Hak Tanggungan harus dilaksanakan atas perintah Ketua Pengadilan Negeri (fiat eksekusi), kalau tetap harus menggunakan fiat dari pengadilan tentu Pasal 6 Undang-Undang Hak Tanggungan menjadi kehilangan makna dan parate eksekusi sama saja dengan eksekusi menggunakan grosse akta hipotek dan surat utang yang mempunyai title eksekutorial, ciri pokok dari Parate Eksekusi berdasarkan janji untuk menjual atas kekuasaan sendiri tanpa harus ada title eksekutorial dan tanpa ada campur tangan dari pengadilan menjadi tidak bisa dilaksanakan. Hal inilah yang menarik penulis untuk dikaji karena telah terjadi konflik norma antara Pasal 6 Undang-Undang Hak Tanggungan (hukum materiil) dan pasal 224 HIR yang mengatur hukum acara eksekusi (hukum formil).

Dasar hukum eksekusi menurut Undang-Undang Nomor 4 Tahun 1996 tentang Hak Tanggungan Atas Tanah Beserta Benda-Benda yang berkaitan dengan Tanah diatur di dalam Pasal 6 yang berbunyi:Apabila debitor cidera janji, pemegang Hak Tanggungan pertama mempunyai hak untuk menjual obyek Hak Tanggungan atas kekuasaan sendiri melalui pelelangan umum serta mengambil pelunasan piutangnya dari hasil penjualan tersebut.

Pasal 6 tersebut memberikan hak bagi pemegang Hak Tanggungan untuk melakukan parate eksekusi. Artinya pemegang Hak Tanggungan tidak perlu bukan saja memperoleh persetujuan dari pemberi Hak Tanggungan, tetapi juga tidak perlu meminta penetapan dari pengadilan setempat apabila akan melakukan eksekusi atas Hak Tanggungan yang menjadi jaminan utang debitor dalam hal debitor cidera janji.

Pemegang Hak Tanggungan dapatlangsung datang dan meminta kepada Kepala Kantor Lelang untuk melakukan pelelangan atas obyek Hak Tanggungan yang bersangkutan. Karena kewenangan pemegang Hak Tanggungan pertama itu merupakan kewenangan yang diberikan oleh undang- undang (kewenangan tersebut dipunyai demi hukum), maka Kepala Kantor Lelang Negara harus menghormati dan mematuhi kewenangan tersebut. ${ }^{17}$

Hak untuk menjual obyek Hak Tanggungan atas kekuasaan sendiri merupakan salah satu perwujudan dari kedudukan diutamakan yang dipunyai oleh pemegang Hak Tanggungan, atau oleh pemegang Hak Tanggungan pertama dalam hal terdapat lebih dari satu pemegang Hak Tanggungan, sebagaimana yang dimaksudkan dalam penjelasan Pasal 6Hak untuk menjual obyek Hak Tanggungan atas kekuasaan sendiri

${ }^{17}$ Sutan Remy Syahdeini, 1999, Hak Tanggungan, Asas-asas, Ketentuan-ketentuan Pokok dan Masalah Yang dihadapi Oleh Perbankan, Jakarta, Institut Bankir Indonesia, hlm. 46. 
merupakan salah satu perwujudan dari kedudukan diutamakan yang dipunyai oleh pemegang Hak Tanggungan atau pemegang Hak Tanggungan Pertama dalam hal terdapat lebih dari satu pemegang Hak Tanggungan. Hak tersebut didasarkan pada janji yang diberikan oleh pemberi Hak Tanggungan bahwa apabila debitor cidera janji, pemegang Hak Tanggungan berhak untuk menjual obyek Hak Tanggungan melalui pelelangan umum tanpa memerlukan persetujuan lagi dari pemberi Hak Tanggungan dan selanjutnya mengambil pelunasan piutangnya dari hasil penjualan itu lebih dahulu dari pada kreditor-kreditor yang lain. Sisa hasil penjualan tetap menjadi hak pemberi Hak Tanggungan.

Ketentuan ini memberikan kepastian bagi Perbankan apabila debitur cidera janji dengan memberikan kemungkinan dan kemudahan untuk pelaksanaan parate eksekusi sebagaimana diatur dalam Pasal 224 HIR dan Pasal 258 RBG ${ }^{18}$. Berdasarkan ketentuan ini juga sekaligus terkandung karakter parate eksekusi dan menjual atas kekuasaan sendiri, namun penerapannya mengacu pada ketentuan Pasal 224 HIR dan Pasal 256 RBG, dimana apabila tidak diperjanjikan kuasa menjual sendiri, penjualan lelang harus diminta kepada Ketua Pengadilan Negeri dan permintaan tersebut berdasarkan alasan cidera janji atau wanprestasi. ${ }^{19}$

Secara umum eksekusi merupakan pelaksanaan atau keputusan pengadilan atau akta, maka pengambilan pelunasan kewajiban kreditor melalui hasil penjualan bendabenda tertentu milik debitur. Perlu disepakati terlebih dahulu bahwa yang dinamakan eksekusi adalah pelaksanaan keputusan pengadilan atau akta. Tujuan dari pada eksekusi adalah pengambilan pelunasan kewajiban debitur melalui hasil penjualan benda-benda tertentu milik debitur atau pihak ketiga pemberi jaminan ${ }^{20}$.

Eksekusi tersebut dilakukan kreditur dengan mengajukan permohonan kepada Ketua Pengadilan Negeri agar terhadap sertifikat hak tanggungan tersebut dilakukan eksekusi. Permohonan tersebut diajukan dengan cara menyerahkan sertifikat hak tanggungan kepada Ketua Pengadilan Negeri yang disertai dengan permohonan agar diterbitkan fiat eksekusi atau surat perintah eksekusi, sehingga eksekusi dapat dijalankan bahkan dengan bantuan aparat keamanan sekalipun. Cara demikian lebih efektif karena tidak membutuhkan proses litigasi dalam arti tidak harus menunggu proses yang memakan waktu lama dengan biaya yang besar ${ }^{21}$.

Mengenai eksekusi riil atas obyek Hak Tanggungan yang dijual, baik dalam hal melalui PN berdasarkan Pasal 224 HIR ataupun melalui kekuasaan sendiri berdasarkan Pasal 6, karena tidak diatur didalam UUHT, maka pelaksanaan eksekusi riilnya tunduk kepada ketentuan umum yang digariskan Pasal 200 ayat (11) HIR yaitu jika pemberi Hak Tanggungan tidak mau atau enggan mengosongkan/meninggalkan Obyek Hak Tanggungan yang telah dijual lelang kepada pembeli lelang, pemegang Hak Tanggungan semula atau pembeli lelang, dapat meminta kepada Ketua PN mengeluarkan atau

\footnotetext{
${ }^{18}$ Bambang Setijoprodjo, 1996, Pengamanan Kredit Perbankan Yang Dijamin Oleh Hak Tanggungan. ,Medan, Lembaga Kajian Hukum Bisnis USU Medan, hlm. 63.

${ }^{19}$ Yahya Harahap, 2005, Ruang Lingkup Permasalahan Eksekusi Bidang Perdata, Jakarta, Sinar Grafika, hlm. 197.

${ }^{20}$ Daniel Romi Sihombing, Perlindungan Hukum Bagi Debitur Wanprestasi Dalam Eksekusi Jaminan Fidusia Berdasarkan Undang-Undang Nomor 42 Tahun 1999 Tentang Fidusia, Jurnal Hukum Media Justitia Nusantara Vo. 6 No. 1 Februari 2019. hlm. 31.

${ }^{21}$ Dimas Nur Arif Putra Suwandi, Perlindungan Hukum Bagi Bank Pemegang Hak Tanggungan Peringkat Kedua Dalam Eksekusi Objek Hak Tanggungan, Media Iuris Vo. 1 No. 3, Oktober 2018, hlm. 431.
} 
menerbitkan surat penetapan yang berisi perintah kepada juru sita supaya melakukan eksekusi riil berupa pengosongan obyek tersebut, jika perlu dengan bantuan polisi.

Sebagaimana telah dijelaskan sebelumnya bahwa fungsi utama lembaga jaminan adalah di satu sisi merupakan kebutuhan bagi kreditur atau Bank untuk memperkecil resiko dalam menyalurkan kredit. Di sisi lain jaminan sebagai sarana perlindungan bagi keamanan kreditor, yaitu kepastian atas pelunasan hutang debitor atau pelaksanaan suatu prestasi oleh debitor atau oleh penjamin debitor, apabila debitor tidak mampu menyelesaikan segala kewajiban yang berkenaan dengan kredit tersebut. Selama kewajiban memnuhi prestasinya yang dijamin dengan jaminan benda bergerak ataupun benda tidak bergerak dipenuhi oleh debitor dengan baik, maka benda jaminan tidak nampak perannya tetapi manakala debitor tidak memenuhi kewajibannya sesuai dengan yang diperjanjikan dengan kreditor, dalam hal demikian debitor dikatakan telah cedera janji, dengan demikian fungsi benda jaminan baru nampak kegunanannya.

Jika dilihat dalam pembahasan di atas, pada dasarnya parate executie atau pelelangan di bawah tangan terhadap objek dari jaminan hak tanggungan merupakan hal yang legal dilakukan oleh kreditor dengan sepersetujuan dari debitor, walaupun dalam banyak pasal dijelaskan mekanisme pelelangan umum dan pendaftaran atas hak tanggungan melalui pengadilan negeri menjadi suatu keharusan untuk memeproleh perlindungan yang lebih baik dan formil secara hukum.

Apabila berbicara mengenai perlindungan hukum bagi kreditor, maka terdapat dua bentuk perlindungan yang dapat diperoleh kreditor. Bentuk perlindungan hukum yang pertama adalah perlindungan hukum secara preventif. Secara garis besar dapat dijelaskan bahwa bentuk perlindungan ini mencoba melindungi kreditor sebelum terjadinya suatu hal-hal ataupun tindakantindakan yang dilakukan oleh debitor dalam upaya pemenuhan prestasinya. Perlindungan hukum secara preventif muncul ketika lahirnya hak kebendaan pada kreditor pemegang Hak Tanggungan atas Obyek Hak Tanggungan yang dijaminkan oleh debitor pemberi Hak Tanggungan. Hak kebendaan tersebut lahir ketika perjanjian atau Akta.

Pembebanan Hak Tanggungan (APHT) beserta sertifikat tanah yang menjadi obyek Hak Tanggungan tersebut didaftarkan pada Kantor Pertanahan. Dalam Pasal 13 ayat (1) jo. penjelasan Pasal 13 ayat (1) UUHT menyatakan bahwa salah satu asas dari Hak Tanggungan adalah publisitas, oleh karenanya harus dilakukan pendaftaran di Kantor Pertanahan. Syarat bahwa akta pembebanan Hak Tanggungan tersebut harus didaftarkan adalah syarat mutlak untuk lahirnya Hak Tanggungan tersebut.

Perlindungan hukum secara preventif lahir ketika lahirnya hak kebendaan pada kreditor pemegang Hak Tanggungan atas Obyek Hak Tanggungan, akan tetapi hak kebendaan tersebut baru lahir ketika para pihak mendaftarkan akta Hak Tanggungan yang telah dibuat oleh para pihak dihadapan Pejabat Pembuat Akta Tanah (untuk selanjutnya disingkat PPAT) pada Kantor Pertanahan, maka dengan demikian dapat disebutkan bahwa lahirnya perlindungan hukum secara preventif kepada kreditor pemegang Hak Tanggungan adalah sejak para pihak mendaftarkan akta Hak Tanggungan pada Kantor Pertanahan. 
Bentuk perlindungan hukum yang kedua adalah perlindungan hukum secara represif. Perlindungan hukum secara represif ini baru muncul ketika debitor pemberi Hak Tanggungan wanprestasi atau cedera janji dengan tidak melaksanakan prestasinya sesuai dengan perjanjian kredit yang disepakati. Undang-Undang memberikan jalan kepada kreditor pemegang Hak Tanggungan untuk melakukan eksekusi terhadap Obyek Hak Tanggungan yang dijadikan sebuah jaminan dalam perjanjian hutang-piutang atau perjanjian pemberian kredit tersebut. Dalam Undang-Undang Hak Tanggungan ada berbagai macam cara yang diberikan kepada kreditor pemegang Hak Tanggungan untuk melakukan eksekusi terhadap Obyek Hak Tanggungan. Landasan hukum yang digunakan untuk melakukan eksekusi Hak Tanggungan didalam UndangUndang Hak Tanggungan adalah Pasal 20 UUHT.

Di dalam ketentuan Pasal 20 UUHT menyebutkan bahwa :

(1) Apabila debitor cidera janji, maka berdasarkan:

a. Hak pemegang Hak Tanggungan pertama untuk menjual obyek Hak Tanggungan sebagaimana dimaksud dalam Pasal 6, atau

b. Titel eksekutorial yang terdapat dalam sertipikat Hak Tanggungan sebagaimana dimaksud Pasal 14 ayat (2).

Obyek Hak Tanggungan dijual melalui pelelangan umum menurut tata cara yang ditentukan dalam peraturan perundang-undangan untuk pelunasan piutang pemegang Hak Tanggungan dengan hak mendahulu daripada kreditor-kreditor lainnya.

(2) Atas kesepakatan pemberi dan pemegang Hak Tanggungan, penjualan obyek Hak Tanggungan dapat dilaksanakan dibawah tanganjika demikian ituakan dapatdiperoleh harga tertinggi yang menguntungkan semua pihak.

(3) Pelaksanaan penjualan sebagaimana dimaksud pada ayat (2) hanya dapat dilakukan setelah lewat 1 (satu) bulan yang diberitahukan secara tertulis oleh pemberi dan/atau pemegang Hak Tanggungan kepada pihak-pihak yang berkepentingan dan diumumkan sedikit-dikitnya dalam 2 (dua) surat kabar yang beredar didaerah yang bersangkutan dan/atau media massa setempat, serta tidak ada pihak yang menyatakan keberatan.

(4) Setiap janji untuk melaksanakan eksekusi Hak Tanggungan dengan cara yang bertentangan dengan ketentuan pada ayat (1), ayat (2), dan ayat (3) batal demi hukum.

(5) Sampai saatpengumumanuntuklelangdikeluarkan, penjualan sebagaimana dimaksud pada ayat (1) dapat dihindarkan dengan pelunasan utang yang dijamin dengan Hak Tanggungan itu beserta biaya-biaya eksekusi yang dikeluarkan.

Dengan melihat ketentuan di atas, maka ada berbagai macam cara yang bisa ditempuh oleh kreditor pemegang Hak Tanggungan untuk melakukan eksekusi terhadap Obyek Hak Tanggungan guna mendapatkan pelunasan piutangnya.

Salah satu cara yang diberikan kepada kreditor pemengang Hak Tanggungan adalah eksekusi yang didasarkan pada Pasal 6 UUHT yakni menggunakan cara parate executie. Apabila seorang debitor pemberi Hak Tanggungan melakukan wanprestasi atau cidera janji, maka sesuai dengan ketentuan Pasal 6 UUHT, kreditor pemegang Hak Tanggungan pertama mempunyai hak untuk menjual obyek Hak Tanggungan atas kekuasaan sendiri. 
Disini pembuat Undang-Undang bermaksud untuk mempermudah bagi kreditor pemegang Hak Tanggungan untuk mendapatkan pelunasan atas piutangnya.

Dalam cara tersebut diperbolehkan bagi kreditor untuk menjual obyek Hak Tanggungan atas kekuasaan sendiri atau lebih dikenal dengan istilah parate executi. Dalam parate executie tidak perlu diperjanjikan kembali, karena parate executie muncul secara otomatis atau dengan sendirinya setelah perjanjian hutang piutang disertai dengan jaminan Obyek Hak Tanggungan dibuat oleh para pihak. Dengan kata lain bahwa ketentuan mengenai parate executie ini tidak perlu diperjanjikan kembali.

Menurut Sutan Remi, Parate executie ini dalam pelaksanaanya mengalami banyak hambatan. "pada kenyataannya, kantor lelang negara tidak bersedia melaksanakan eksekusi tersebut. Cukuplah apabila pemegang Hak Tanggungan pertamaitu mengajukan permohonan kepada kepala kantor lelang negara setempat untuk pelaksanaan pelelangan umum dalam rangka eksekusi objek Hak Tanggungan tersebut ${ }^{22}$. Tetapi secara teoritis Pasal 6 UUHT tersebut terkendala dengan Pasal 26 UUHT di mana ketentuan mengenai eksekusi hypotheek masih berlaku terhadap eksekusi hak tanggungan. Artinya pelaksanaan eksekusi hak tanggungan juga merujuk kepada ketentuan Pasal 224 HIR di mana harus dilaksanakan atas perintah ketua pengadilan. Ketentuan pasal inilah yang menurut para ahli hukum mengindikasikan bahwa adanya tumpang tindihnya ketentuan parate eksekusi dalam UUHT ${ }^{23}$.

Dalam hal perlindungan hukum terhadap suatu perjanjian pembebanan Hak Tanggungan serta akibat hukumnya tentu tidak terlepas dari adanya upaya untuk melindungi semua pihak yang terkait. Begitu pula dalam hal debitor pemberi Hak Tanggungan, juga harus diberi porsi yang sama sebagai bentuk perlindungan hukumnya ${ }^{24}$.

Berbicara mengenai perlindungan hukum, sudah pasti ada dua jenis bentuk, yakni preventif dan represif. Sesuai dengan pembahasan sebelumnya, bahwa bentuk perlindungan hukum secara preventif pada dasarnya memberikan perlindungan sebelum terjadinya suatu yang tidak diinginkan atau dengan kata lain perlindungan ini sebagai bentuk pencegahan terjadinya hal-hal yang bisa merugikan para pihak yang saling mengikatkan dalam suatu perjanjian.

Bentuk perlindungan hukum secara preventif ini didapat oleh debitor pemberi Hak Tanggungan sejak pra perjanjian kredit dengan jaminan antara kreditor dengan debitor. Setelah debitor mengajukan proposal permohonan kredit kepada kreditor (dalam hal ini bank) maka proposal tersebut akan diolah dengan mempertimbangkan berbagai hal guna keamanan kredit yang diberikan oleh kreditor. Dalam hal perjanjian kredit tersebut disertai dengan jaminan kebendaan, maka perlu dan wajib diadakan penilaian terhadap jaminan yang akan digunakan dalam menjamin kredit tersebut ${ }^{25}$.

Perlindungan secara represif terhadap aset debitor pemberi Hak Tanggungan juga terjadi atas penentuan harga lelang. Dalam hal penentuan harga lelang, terlebih dahulu balai lelang akan mengadakan musyawarah dengan kreditor dan debitor untuk

\footnotetext{
${ }^{22}$ J. Andy Hartanto, 2015, Hukum Jaminan dan Kepailitan Hak Kreditor Separatis Dalam Pembagian Hasil Penjualan Benda Jaminan Debitor Pailit, Laksbang Justitia, Surabayar, hlm. 99.

${ }^{23}$ Amran Suadi, 2019, Eksekusi Jaminan Dalam Penyelesaian Sengketa Ekonomi Syariah, Kencana, Jakarta, hlm.

${ }^{24}$ Yusuf Arif Utomo, Parate Executie Pada Hak Tanggungan Sebagai Perlindungan Aset Kreditor dan Debitor, Yuridika, Volume 26, No. 2, Mei - Agustus 2011, hlm. 195.

${ }^{25}$ Ibid
} 58 . 
menentukan penetapan harga limit lelang, sehingga tidak merugikan salah satu pihak. Dalam hal penentuan harga limit lelang biasanya dibagi menjadi tiga bagian, yang pertama harga tertinggi atas Obyek Lelang. Harga ini mengacu pada harga yang ada di pasaran. Dengan harga ini mungkin akan didapatkan harga jual tertinggi atas Obyek Lelang, sehingga dapat memuaskan debitor pemberi Hak Tanggungan selaku pemegang Hak Kebendaan.

Selain itu juga menurut Boedi Harsono dalam jurnal Muh. Akbar Azis Purnomo juga menyebutkan beberapa perlindungan bagi debitur, pemberi Hak Tanggungan ${ }^{26}: 1$. Perlindungan yang Seimbang Hukum bukan hanya memperhatikan kepentingan kreditur tetapi perlindungan juga diberikan kepada debitur dan pemberi Hak Tanggungan. 2. Syarat Spesialitas Dalam APHT selain nama, identitas dan domisili kreditur dan pemberi Hak Tanggungan, wajib disebutkan juga secara jelas dan pasti piutang yang mana yang dijamin dan jumlahnya atau nilai tanggungannya. Juga uraian yang jelas dan pasti mengenai benda-benda yang ditunjuk menjadi obyek Hak Tanggungan Pasal 11 UUHT. 3. Syarat Publisitas Agar adanya Hak Tanggungan tersebut siapa kreditur pemegangnya, piutang yang mana dan berapa jumlahnya yang dijamin serta bendabenda yang mana yang dijadikan jaminan dengan mudah dapat diketahui oleh pihakpihak yang berkepentingan, wajib dipenuhi apa yang disebut syarat publisitas yaitu pemberian Hak Tanggungan wajib didaftarkan di Kantor Pertanahan. 4. Janji yang Dilarang Dalam rangka melindungi kepentingan pemberi Hak Tanggungan dalam Pasal 12 UUHT, dilarang pemberian Hak Tanggungan disertai janji, bahwa apabila debitur cidera janji kreditur karena hukum akan menjadi pemilik obyek Hak Tanggungan. Kalaupun diadakan janji demikian itu batal demi hukum.

\section{Hambatan-Hambatan Dalam Melindungi Kepentingan Kreditur Dan Debitur Terhadap Pelelangan Obyek Hak Tanggungan Melalui Parate Executie Dan Solusi Untuk Mengatasi Hambatan-Hamabatan Tersebut.}

Berdasarkan kajian berbagai sumber dapat dikelompokan beberapa hambatan dalam pelaksanaan parate executie terhadap kreditor yaitu:

1. Hambatan yuridis

Hambatan yuridis yang akan timbul dan mempunyai implikasi sosiologis yang dapat menjadi kendala pelaksanaan penjualan obyek jaminan dengan cara dibawah tangan adalah keharusan mengumumkan pelaksanaan penjualan obyek jaminan tersebut dalam 2 (dua) surat kabar yang beredar di daerah yang bersangkutan dan atau media massa setempat agar apabila ada kreditor lain yang juga dijamin dengan obyek jaminan tersebut terlindungi hak-haknya serta untuk menjamin tidak ada pihak yang berkeberatan. Hal ini apabila dilaksanakan tentu akan menimbulkan beban moril bagi debitor dan atau penjamin karena kondisinya akan diketahui kolega atau rekan bisnis serta lingkungannya yang bisa berakibat pada kelangsungan usahanya.

2. Hambatan non yuridis

a. Debitor Tidak Kooperatif

\footnotetext{
${ }^{26}$ Muh. Akbar Azis Purnomo, Perlindungan Hukum Bagi Pemberi Hak Tanggungan Yang Bukan Debitur Dalam Perjanjian Kredit, Unnes Law Journal 3 (1) 2014, hlm. 66.
} 
Debitor yang tidak koperatif saat akan dilakukan pelelangan langsung tanpa melalui pengadilan; misalkan awalnya ingin aktif mencarikan pembeli, namun sengaja mengulur waktu agar obyeknya tidak terjual;

b. Hambatan debitor pailit

Jika sewaktu-waktu jaminan akan dilakukan eksekusi, namun ketika diajukan permohonan pailit terhadap si debitor oleh kreditor lainnya, maka, objek jaminan tersebut tidak akan dilakukan eksekusi dalam waktu cepat, namun harus ditunda karena obyek tersebut akan masuk dan dijadikan sebagai boedl/harta pailit. ${ }^{27}$

c. Hambatan Eksekusi

Dalam praktik seringkali eksekusi jaminan hak tanggungan tidak selalu memberikanperlindunganhukumkepadapembelilelangobjekhaktanggungan,salah satunyapembelilelangtidakdapatmenikmatihaknyaatasobjeklelangkarenaadanya gugatan atas eksekusi objek hak tanggungan berupa gugatan perlawanan maupun gugatan kepada pembeli lelang, sehingga eksekusi objek lelang hak tanggungan tidak dapat dilaksanakan. ${ }^{28}$

d. Obejek Hak Tanggungan Dikuasai Pihak Ketiga

Masalah ini banyak ditemukan dalam permohonan eksekusi hak tanggungan syariah ke pengadilan agama, bisa dalam bentuk objek tersebut sedang dikuasai oleh orang lain (pihak ketiga) yang merasa memiliki atas objek tersebut atau pihak ketiga yang merupakan pemilik awal objek tanah yang merasa masih berhak menduduki tanahyang telahiajual kepada debitur (termohon eksekusi), sehingga pada akhirnya proses eksekusi tidak berjalan mulus mulai dari adanya penolakan, keributan, sampai hal-hal yang lebih luas seperti mengerahkan massa ${ }^{29}$.

e. Pemegang Hak Tanggungan Kedua, Ketiga dan Seterusnya Melakukan Perlawanan.

Sesuaidenganasasdroitdepreference, makadalameksekusiobjekhaktanggungan, hak kebendaan yang lebih dahulu terjadi akan lebih diutamakan daripada yang terjadi kemudian atua sering juga disebut asas prioritas. Dalam praktiknya, kerap terjadi di mana ketika pelaksanaan eksekusi dilakukan atas permohonan pemegang hak tanggungan pertama atau pada saat sita eksekusi, pemegang hak tanggungan kedua, ketiga, dan seterusnya melakukan perlawanan yang diajukan ke pengadilan agama $^{30}$.

f. Perlawanan dari Pihak Ketiga Atas Dasar Kepemilikan

Praktiknya di beberapa pengadilan agama yang sedang melakukan eksekusi lelang atas objek hak tanggungan pernah dijumpai adanya pihak ketiga yang merasa keberatan dengan adanya lelang yang dilaksanakan dengan alasan bahwa objek yang akan atau sedang dilelang adalah miliknya. Perlawanan pihak ketiga tersebut atau disebut dengan Deden Verzet harus diajukan ke pengadilan agama setempat. Pihak ketiga harus melampirkan alat bukti tentang kepemilikannya atas obejk

${ }^{27}$ Moh. Anwar, Perlindungan Hukum Terhadap Kreditur Dalam Perjanjian Kredit Dengan Jaminan Hak Tanggungan Menurut Undang-Undang No. 4 Tahun 1996, "JENDELA HUKUM" Fakultas Hukum UNIJA. Volume I Nomor 1 April 2014, hlm. 7.

${ }_{28}^{28}$ Mohammad Aligifari Sukmaya, dkk, Perlindungan Hukum Bagi Pemenang Lelang Objek Hak Tanggungan Dalam Hal Eksekusi Terhalang Oleh Gugatan Ditinjau Dari Hukum Jaminan, Dialogia Iuridica, Jurnal Hukum Bisnis dan Investasi, Faculty of Law, Padjajaran University Volume 11 Nomor 2, April 2020, hlm. 118.

${ }^{29}$ Amran Suadi, Op. Cit, hlm. 71

${ }^{30}$ Ibid 
hak tanggungan yang akan atau sedang dilelang, misalnya sertifikat hak milik dan lain-lain ${ }^{31}$.

Untukmengatasi hambatan-hambatan dalam pelaksanaan parate executie terhadap obyek hak tanggungan, maka ada beberap solusi yang dilakukan adalah melalui opsi penjualan di bawah tangan, selama debitur juga kooperatif, maka pengadilan dapat memaksimalkan jalan penyelesaian ini. Pengadilan dengan persetujuan kreditur dan debitur mempersilahkan mencari pembeli sendiri dengan harapan didapatkan pembeli denganhargayangtinggi.Pelaksanaanyadilakukanatasperintahketuapengadilanagama di mana objek hak tanggungan itu terletak, setelah adanya permohonan pengosongan dari pihak pemenang lelang sebagai pemegang hak atas tanah dan bangunannya yang baru $^{32}$.

Pemegang hak tanggungan kedua, ketiga dan seterusnya melakukan perlawanan. Dalam menghadapi perlawanan demikian, hakim/ketua pengadilan harus menolak, karena perlawanan terhadap sita eksekusi hanya dapat dilakukan oleh pihak ketiga atas dasar dalil adanya kepemilikan. Pemegang hak tanggungan kedua, ketiga, dan seterusnya bukanlah pemilik, tetapi ia mempunyai hak untuk memohon pelunasan piutangnya yang juga dijamin atas tanah yang disita eksekusi tersebut. Pemegang hak tanggungan kedua, ketiga, dan seterusnya jika ingin agar pelunasan piutangnya dibayar, maka caranya dengan mengajukan permohonan eksekusi ke pangadilan tersebut atas dasar hak tanggungan yang dimilikinya. Sehingga perolehan uang dari hasillelang eksekusi tersebut, setelah dibayarkan terlebih dahulu kepada pemegang hak tanggungan pertama, kemudian sisanya jika masih ada dibayarkan kepada pemegang hak tanggungan kedua, ketiga, dan seterusnya. Perlawanan pihak ketiga secara yuridis sebenarnya tidak mengakibatkan eksekusi harus ditangguhkan (vide Pasal 207 ayat (3) HIR dan $227 \mathrm{RBg}$ ), namun dalam keadaan tertentu langkah penangguhan proses eksekusi atau lelang dapat ditempuh oleh ketua pengadilan agama sepanjang ada alasan yang mendasarinya ${ }^{33}$.

\section{SIMPULAN}

Perlindungan hukum bagi pihak khususnya kreditur dalam pelaksanaan pelelangan parate executie hak tanggungan tidak ada kepastian hukum karena terdapatnya norma yang tumpang tindih dalam UUHT, sekalipun dalam UUHT diatur perlindungan bagi para pihak baik secara prefentif maupun secara reprensif.

Hambatan-hambatan yang dihadapi dalam perlindungan hukum bagi pihak kreditur melalui parate executie obyek hak tanggungan terdiri dari hambatan yuridis dan non yuridis. Hambatan yuridis terjadi karena adanya norma yang tumpang tindih sedangkan hambatan non yuridis terjadi karena: a) Debitor Tidak Kooperatif, b) Hambatan debitor pailit, c) Hambatan Eksekusi, d) Obejek Hak Tanggungan Dikuasai Pihak Ketiga, e) Pemegang Hak Tanggungan Kedua, Ketiga dan Seterusnya Melakukan Perlawanan, dan f) Perlawanan dari Pihak Ketiga Atas Dasar Kepemilikan. Untuk mengatasi hambatanhambatan tersebut solusi yang ditawarkan adalah penjualan di bawah tangan, hakim

\footnotetext{
${ }^{31}$ Ibid

${ }^{32}$ Ibid

${ }^{33}$ Ibid
} 
dapat menolak tuntutan dari pihak yang melakukan perlawanan, dapat mengajukan permohonon eksekusi ke pengadilan dan dapat melakukan penangguhan lelang eksekusi.

\section{DAFTAR PUSTAKA}

\section{Buku}

Arba, M. dan Mulada, Ade, Diman, (2020). Hukum Hak Tanggungan, Hak Tanggungan Atas Tanah dan Benda-Benda di Atasnya, Sinar Grafika, Jakarta,

Harahap, Yahya, (2005), Ruang Lingkup Permasalahan Eksekusi Bidang Perdata, Jakarta, Sinar Grafika.

Harsono, Sony, (1996), Sambutan MenteriAgraria/Kepala BPNpada Seminar Hak Tanggungan alas Tanah dan Benda-Benda yang Berkaitan dengan Tanah, Fakultas Hukum UNPAD, Bandung,.

Hartanto, J. Andy, (2015), Hukum Jaminan dan Kepailitan Hak Kreditor Separatis Dalam Pembagian Hasil Penjualan Benda Jaminan Debitor Pailit, Laksbang Justitia, Surabayar.

Hasan, Djuhaendah, (1996), Lembaga Jaminan Kebendaan Bagi Tanah dan Benda Lain yang Melekat Pada Tanah Dalam Konsepsi Penerapan Asas Pemisahan Horisontal, Citra Aditya Bakti, Bandung.

Isnaeni, M., (1996), Hipotek Pesawat Udara Dilndonesia, CV. Dharma Muda, Surabaya.

Poesoko, Herowati, (2007), Parate Executie Obyek Hak Tanggungan (Inkositensi, Konflik Norma dan Kesesatan Penalaran dalam UUHT), Laks Bang PRESSindo, Yogyakarta.

Poesoko, Herowati, (2012), Dinamika Hukum Parate Executie Obyek Hak Tanggungan, Aswaja Pressindo, Yogyakarta.

Rosyadi, Imron, (2007), Jaminan Kebendaan Berdasarkan Akad Syariah (Aspek Perikatan, Prosedur Pembebanan dan Eksekusi), Kencana.

Satrio,J., (2007), Hukum Jaminan HakJaminan Kebendaan, Citra Aditya Bakti, Bandung, cetakan ke 5.

Setijoprodjo, (1996), Bambang, Pengamanan Kredit Perbankan Yang Dijamin Oleh Hak Tanggungan. ,Medan, Lembaga Kajian Hukum Bisnis USU Medan.

Suadi, Amran, (2019), EksekusiJaminan Dalam Penyelesaian Sengketa Ekonomi Syariah, Kencana, Jakarta.

Sutan Remy Sjahdeni, (1999), Hak Tanggungan AsasAsas, Ketentuan Pokok, dan Masalah yang Dihadapi Oleh Perbankan, Alumni, Bandung.

Sutantio,Retnowulan, (1999), Penelitian Tentang Perlindungan Hukum Eksekusi Jaminan Kredit, Badan Pembinaan Hukum Nasional-Departemen Kehakiman RI, Jakarta.

\section{Jurnal dan lainnya}

Anwar, M. (2014). Perlindungan Hukum Terhadap Kreditur dalam Perjanjian Kredit dengan Jaminan Hak Tanggungan Menurut Undang-Undang No. 4 Tahun 
1996. Jurnal Jendela Hukum, 1(1).

Purwadi, Ari, (1997), Problematika Hak Tanggungan Menurut Undang-Undang Nomor 4 Tahun 1996. Jurnal Hukum Ekonomi, Edisi IX Agustus 1997.

Purnomo, M. A. A. (2014). Perlindungan Hukum bagi pemberi Hak Tanggungan yang bukan Debitur dalam perjanjian Kredit. Unnes Law Journal, 3(1).

Rimanda, R., \& Yusri, Y. (2019). PERLINDUNGAN HUKUM BAGI KREDITUR DALAM PEMBIAYAAN DENGAN JAMINAN HAK TANGGUNGAN (Studi pada Kantor Pusat PT. Bank Aceh Syariah di Provinsi Aceh). Jurnal Imiah Mahasiswa Bidang Hukum Keperdataan, 3(1), 157-164.

Sihombing, D. R. (2019). Perlindungan Hukum Bagi Debitur Wanprestasi Dalam Eksekusi Jaminan Fidusia Berdasarkan Undang-Undang Nomor 42 Tahun 1999 Tentang Fidusia. JURNAL HUKUM MEDIA JUSTITIA NUSANTARA, 6(1).

Sukmaya, M. A., Abubakar, L., \& Handayani, T. (2020). PERLINDUNGAN HUKUM BAGI PEMENANG LELANG OBJEK HAK TANGGUNGAN DALAM HAL EKSEKUSI TERHALANG OLEH GUGATAN DITINJAU DARI HUKUM JAMINAN. Jurnal Mmiah Galuh Justisi, 8(2), 204-229.

Sulastri, L. (2016). Konstruksi Perlindungan Hukum Debitur dalam Penyelesaian Kredit Bermasalah dengan Pelaksanaan Lelang Jaminan Hak Tanggungan. Jurnal Pembaharuan Hukum, 2(1), 86-101.

Suwandi, D. N. A. P. (2018). Perlindungan Hukum Bagi Bank Pemegang Hak Tanggungan Peringkat Kedua Dalam Eksekusi Objek Hak Tanggungan. Media Iuris, 1(3), 420-438.

Utomo, Y. A. (2011). PARATE EXECUTIE PADA HAK TANGGUNGAN SEBAGAI PERLINDUNGAN ASET KREDITOR DAN DEBITOR. Yuridika, 26(2), 176202.

Indonesia, Undang-Undang Nomor 4 Tahun 1996 Tentang Hak Tanggungan Atas Tanah Beserta Benda-Benda Yang Berkaitan Dengan Tanha, Lembaran Negara Republik Indonesia Nomor 42 Tahun 1996. 